\title{
Ensayo \\ El país que empezó a verse único
}

PhD. Florentino Rodao ${ }^{1}$

Universidad Complutense de Madrid, España

tinorodao@ccinf.ucm.es

Llovió sobre mojado. La victoria en la lucha contra Rusia culminó una especie de década prodigiosa para el Japón Meiji en la que, por primera vez desde 1868, los frutos de las tres décadas de reformas empezaron a palparse. Habían traído desesperación y hambre, y se pudieron extender muy lentamente a lo largo de un país dividido en unos 270 dominios feudales durante los últimos siglos. Tampoco habían faltado las protestas, unas espontáneas y otras con una base más amplia, organización e incluso con líderes nacionales, como la de Takamori Saigō que relata en El último samurai con tanta admiración como exotismo Edward Zwick (los carlistas serían los héroes si realizara una película sobre la España del XIX, seguro: han sido elogiados hasta por Karl Marx). Hizo falta tranquilidad, cuando menos, hasta que la victoria sobre la China Imperial de la guerra de 1894-95 cambió la marcha del país. La apatía se convirtió en un creciente orgullo nacional, mientras que la nueva estructura nacional definida tras la constitución de 1889 (el Kokutai, 国体, "la esencia de la nación") y el nuevo imperio encumbraron los cambios de la era Meiji. Las reformas puestas en marcha décadas antes se implantaron definitivamente, porque fue a partir de finales de siglo cuando, por ejemplo, se generalizó la asistencia a las escuelas del gobierno o cuando se extendió a la mayoría de los pueblos del país la celebración de las nuevas festividades, como el cumpleaños del emperador o el día nacional de Japón.

La imagen al exterior cambió, por primera vez acuñada también desde el propio archipiélago. Hasta entonces, había sido percibido desde el prisma orientalista, tal como reflejaban la famosa

$1 \quad$ Historiador español, profesor de la Universidad Complutense de Madrid, especializado en Historia de Asia y en las relaciones asiáticas con España. Doble doctor en Historia Contemporánea (Universidad Complutense de Madrid) y Arts and Sciences (Universidad de Tokio), ha sido investigador y profesor en distintas universidades de España, Estados Unidos, Japón, Puerto Rico y Filipinas. Ha publicado tanto en español como en inglés y sus obras se han traducido al japonés y al tagalo. 
opereta de Gilbert y Sullivan, Mikado (Emperador de Japón), con un pueblo mortificado por las reglas de etiqueta, o Madame Crisantemo de Pierre Loti, una típica novela colonial de occidental llegado a un lugar exótico, en donde se le enamora una local, a la cual abandonaba para regresar a su país. Tras la victoria sobre China, una avalancha de libros destinados al consumo exterior, escritos por japoneses y aún vigentes, dejaron obsoleta la imagen exótica. Fueron libros como los del historiador del arte Tenshin Okakura, Los ideales del Oriente (1902) y El Libro del Té (1903), o el Bushido. El alma de Japón, escrito por el cuáquero Inazo Nitobe en 1899. O, volviendo a los escenarios, la Madame Butterfly de Giacomo Puccini, un vivo ejemplo de ese cambio tan profundo de la imagen de Japón en apenas unos años. Basada en el drama de David Belasco, de 1900, y este en la novela de Pierre Loti, la principal diferencia es el retrato de los personajes. La de Loti acaba con la Crisantemo contando regocijada los dólares de plata del marino americano, satisfecho por sus servicios. Con la ópera de Puccini, el occidental es un egoísta desalmado que engaña a su amante enamorada. Primero, con una falsa ceremonia de boda, después abandonándola para regresar a su país y, por último, casándose, no atreviéndose a decirlo y enviando a su esposa para dar la noticia. La Butterfly, o Chōchō-san, da la enhorabuena, pero en cuanto se queda sola comete harakiri con la espada de su padre, complementando con el amor la muerte por la patria mitificada en el Bushido. Desde fines del XIX, a Japón se le salía el Oriente: era imposible compaginar el desprecio hacia el mundo masculino de esas visiones exóticas con los radiogramas sobre victorias militares.

La victoria frente al imperio ruso de 1905 condujo a cambios de mayor alcance. No fue un paso adelante en el chovinismo, sino un replanteamiento de su posición en el mundo, porque desde entonces Japón se esforzó por darse y dar a los demás la imagen de ser, más que únicos, incomparables, inimitables e incomprensibles. Japón era -y es - un país peculiar; supo aprovecharse como nadie del empuje colonial, pasó en pocas décadas de temer ser invadido a tratar de tú a las grandes potencias. Además, era objeto de admiración universal, especialmente en países como España o Turquía, que se sentían sobrepasados. Pero ser incomparable iba más allá, y significaba justificar al imperio como una necesidad, lo que se hizo a través de dos ideas que después serían la base del militarismo de la década de 1930. Por un lado, convertirse en los liberadores del continente asiático de la rapiña occidental, y por el otro, la conciencia de ser el país elegido por los dioses. Japón tenía (y tiene) la dinastía más antigua de la historia, pero usó de forma torticera la mitología sobre sus orígenes para no solo ampliarla hasta los dioses creadores del mundo, Amaterasu, Inazagi e Izanagi, o el emperador Jinmu, sino para creerlo, propagarlo y justificar esa singularidad.

El paso del expansionismo al imperialismo fue una vorágine. La población protestó con revueltas violentas el acuerdo de Paz de Portsmouth, donde apenas obtuvo territorios o indemnizaciones, pero al mes siguiente recibió a la flota de forma masiva. Y Japón tomó un curso cada vez más decidido. Aprovechó el fervor popular para una nueva kyōka (las periódicas campañas de movilización organizadas por la burocracia estatal, imbuida de fervor reformista) a favor del pago de los impuestos, mientras que periodistas, educadores o líderes locales se esforzaron por imbuir el Kokutai imperial en la población, y arqueólogos e historiadores se esforzaron por formular teorías sobre la homogeneidad de la raza japonesa o sobre los orígenes del pueblo japonés que se adaptaran a la ambición expansionista. Fue una campaña nacional; los negocios 
ayudaron a la Compañía de Ferrocarriles del Sur de Machuria, que desde 1906 fue el puntal de la penetración económica nipona en el note de Asia, mientras se fundaron grupos ultranacionalistas, unos de carácter más activo, como la Sociedad del Dragón Negro, y otras, más académico, como las Sociedades Asia y Oriente, de académicos. No faltaron los aspectos colaterales, como la estetización de la muerte, lo más conveniente para un ejército con muchos recursos humanos pero pocos materiales: se popularizó la imagen de los cerezos en flor como las almas de los soldados muertos.

A raíz del incidente de Manchuria, en 1931, la dinámica se aceleró y el país vivió los quince años más vertiginosos de su larga historia. En el cenit de su certidumbre como pueblo elegido, Tokio llegó a celebrar en 1940 los 2600 años de la dinastía imperial, que serían, dentro del discurso mitológico-propagandista de entonces, los de la creación del mundo. Y siguiendo ese impulso asiatista, Japón se embarcó en una espiral interminable de guerras con la excusa de liberar a los pueblos asiáticos, aunque su motivo principal, como en muchos otros casos, se limitaba a sustituir a los colonialistas europeos.

En 1945, las bombas atómicas y el final de la Guerra dieron paso a una nueva trayectoria que purgó Japón, desde las ideas totalitarias o el antaño impoluto prestigio de los militares hasta los territorios conquistados desde esa victoria sobre China de 1895. Pero la dinámica puesta en marcha a raíz de la victoria sobre Rusia en 1905 pervive. Japón sigue sintiéndose el líder de Asia y su política exterior de posguerra ha mantenido unas ideas que, si bien permiten la coexistencia con los países occidentales, presuponen ese liderazgo japonés. Lo mismo que ese sentimiento de ser únicos, según señalan las encuestas: se piensa que los extranjeros pueden llegar a hablar el idioma, disfrutar con su comida o relajarse con sus 白本人論s en aguas termales, pero les es imposible penetrar en su forma de pensar. Es la Nihonjinron ( , saber cómo somos o, traducido literalmente, tesis sobre los japoneses), para algunos como Harumi Befu una religión cívica y para otros, cuando menos, una de las principales preocupaciones de los japoneses, a juzgar por los numerosos best sellers que origina. No está claro que sea verdad, pero la Nihonjinron pervive, aunque la "década perdida" de la que habla Fernando Delage la ha dejado tocada, tal como quedaron los famosos Valores Asiáticos tras la crisis financiera de 1997. Sirve para explicar desde fracasos hasta decisiones corporativistas, como que solo sean japoneses quienes puedan enseñar sobre Japón, tal como ha hecho alguna universidad española. Lo mismo que el Spain is different de tiempos pretéritos o algunas soflamas nacionalistas de tiempos más recientes: las apelaciones a la particularidad suelen esconder ambiciones más pedestres. Sirven para rotos y para descosidos. 